\title{
Separate or together? Women-only public spaces and participation of Saudi women in the public domain in Saudi Arabia
}

\author{
Annemarie van Geel ${ }^{1}$
}

Published online: 5 January 2016

(C) The Author(s) 2016. This article is published with open access at Springerlink.com

\begin{abstract}
Gender segregation in the public domain has become a cornerstone of the Saudi interpretation of Islam (Doumato 2009). It is a development that has led to the coming about of extensive separate public spaces that are only for women (Doumato 2009; Hamdan 2005; Le Renard 2008, 2014). In these women-only public spaces, women undertake activities that are by them and for them, therewith reinforcing the existence of these separate structures. This institutionalisation and practice of womenonly public spaces, as well as its opposite phenomenon of 'mixing' between the two sexes (ikhtilatt) however is contested and led to a heated debate. This debate centres around the question of whether and if so, how women should participate in the public domain. Starting with an overview of the historical development of women-only public spaces and ikhtilāt in Saudi Arabia, I will show how these have evolved. Drawing on fieldwork among urban, educated Saudi women, I shed light on how attitudes and strategies of female respondents regarding women-only public spaces and ikhtilāt are related to their ideas about their presence in the public domain and notions of 'the liberation of women', 'empowerment', and 'the rise of women'. I conclude by demonstrating how ideas about the participation of women in the public sphere are positioned as part of the construction of a local, 'enchanted' modernity (Deeb, 2006) that has a material and a spiritual dimension.
\end{abstract}

Keywords Saudi Arabia - Gender segregation - Women-only public spaces · Modernity Empowerment

Annemarie van Geel

a.vangeel@ftr.ru.nl

1 Faculty of Philosophy, Theology, and Religious Studies, Department of Islamic Studies, Radboud University Nijmegen, Erasmusplein 1, P.O Box 9103, 6500 HD Nijmegen, The Netherlands 


\section{Introduction}

In March 2010, Dr. Yusef al-Ahmad, a professor of Islamic jurisprudence at Imam

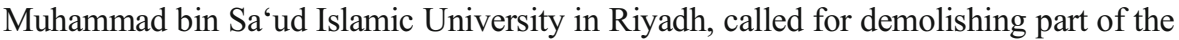
Grand Mosque in Mecca and subsequently constructing separate floors for women in the mosque, so that men and women would be prevented from mixing of the sexes (ikhtilatt) during tawa $f^{t}$ and prayer. Dr. al-Ahmad's proposal was met with both consent (endorsing the practice of gender segregation) and criticism (favouring ikhtilat $t$ ). AlAhmad's statement illustrates the debate about mixing of the sexes that was taking place in Saudi Arabia during the time of research (2010-2011), with some being as strongly in favour of segregation in the public domain as others are in favour of ikhtilät (Foley 2010; Meijer 2010). Central to this debate is the question whether and if so, how women should participate in the public domain.

Gender segregation in the public domain has become a cornerstone of the Saudi interpretation of Islam (Doumato 2009). The gender segregation in the public domain that has come about in Saudi Arabia does not relegate women's participation to the realm of domesticity, but rather separates men and women in the public domain. As such, it is a development that has led to the coming about of extensive separate public spaces that are only for women (al-Rasheed 2013; Doumato 2009; Hamdan 2005; Le Renard 2008 and Le Renard 2014). In these women-only public spaces, women undertake activities that are by them and for them, thereby reinforcing the existence of these separate structures. This institutionalisation and practice of women-only public spaces, as its opposite of ikhtilät, do not go uncontested.

Starting with an overview of the historical development of women-only public spaces and ikhtilät, I will show how these have evolved. Subsequently, this article will disentangle the ideas, attitudes and strategies of interviewed women themselves on the issue of their own participation in Saudi Arabia's public spaces. Then, I examine interlocutors' ideas about 'empowerment' and 'the rise of women' and how these are related to the concepts of women-only public spaces and ikhtilatt. I conclude by demonstrating how ideas about the participation of women in the public sphere are positioned as part of the construction of a local, 'enchanted' modernity (Deeb, 2006) that has a material and a spiritual dimension.

\section{Methodology}

This article is the result of my participation in the Saudi Arabia project of the Islam Research Programme (IRP) of the Dutch Ministry of Foreign Affairs. For the research project on Saudi Arabia, three themes were chosen. These are intellectual trends and debates, civil society, and the position of women. My research concerned the 'position of women' theme and dealt with the challenges and opportunities that interlocutors experience regarding ikhtilät and gender segregation, as apparent in public spaces that are 'only for women'. This article is an adaptation of the section on the position of women in the IRP Saudi Arabia research report 'Saudi Arabia between Conservatism,

\footnotetext{
${ }^{1}$ Circumbulation of the Ka ba (a cubic building inside the Great Mosque of Mecca which is the holiest place of Islam) during hajj (Muslim pilgrimage).
} 
Accommodation and Reform', published by the Clingendael Institute in 2012 (Aarts and Meijer 2012). Paul Aarts, Dr. Roel Meijer, and Prof. Dr. Karin van Nieuwkerk developed the initial research proposal for the overall IRP project on Saudi Arabia. The local partner institute of the IRP project was the King Faisal Institute for Research and Islamic Studies in Riyadh (KFCRIS), who generously hosted me during my fieldwork. For this article, I also draw on insights gained during my $\mathrm{PhD}$ research on the same topic.

For this study, I interviewed a total of 48 women. Fieldwork took place in June 2010, January 2011, and September 2011. The majority of interviews were formal interviews that followed an interview protocol and took place in public areas such as malls and coffee shops, in homes, or in offices. Other interviews took place more informally, such as chance encounters in a clothes shop or during a visit to a theme park. Interviews took place in Arabic or in English, depending on the interlocutor's preference.

The focus of the research were urban women, most of whom were well-educated and well-travelled. Not all had a command of English. The categories of women that I interviewed were young working women, female students, businesswomen, female Islamic preachers and teachers (hereafter called $d a^{6} i y \bar{a} t$ ) and women who work on women's issues (hereafter called activists). They all lived in cities (Riyadh, Jeddah, and Dammam).

The rationale for choosing these categories of interlocutors is that they all have taken on an active role in the public domain and as such navigate and have experience with the issues at hand. For that reason, and because it would have been difficult to gain access to them during the short fieldwork periods, I did not include the category of nonurban women.

During the first, nine-month phase of the research project (2010) the focus was on desk research, which consisted of evaluating the historical development of women-only public spaces, and fieldwork. In June 2010, I carried out fieldwork in Saudi Arabia and interviewed sixteen female students and fourteen young working women about their views and experiences regarding the possibilities and constraints of women-only public spaces and ikhtilatt. All interlocutors were young women who have an active role in the public domain. Three interviews took place in Riyadh, twenty-seven in Jeddah. The majority of interviews were carried out in Arabic and none of the interviews were voice-recorded.

In the final stages of phase one, consultation with Saudi scholars helped refine the research questions and research design for phase two. During the second phase (January-December 2011) of the research project, I conducted in-depth interviews with women who have reached a settled position in society. The three focus categories were businesswomen, activists, and da'iyät. These are all women who have an active role in the public domain.

In January 2011, I carried out two weeks of fieldwork in Riyadh and interviewed nine women: three activists, three da'iyāt, and three businesswomen. All interviews were formal, voice-recorded interviews. In September 2011, I carried out four days of fieldwork in Jeddah and the Eastern Province and interviewed nine women: again three activists, three $d a^{6} i y \bar{a} t$, and three businesswomen. As in January 2011, all interviews were formal, voice-recorded interviews, and the majority of interviews were carried out in Arabic. In phase two, I interviewed a total of eighteen women, leading to a total 
number of forty-eight interviewed women for phases one and two together. In this article, all women have been given a pseudonym.

During my fieldwork I was supported by Saudi research assistants. Assistance consisted of making contacts, helping me find my bearings in Saudi Arabia, and literature search. Key informants were researchers at KFCRIS in Riyadh, one of the Saudi experts who had been involved in phase one of the project, and a Saudi acquaintance. After this initial access to the research field, I relied on referrals (the so-called 'snowball sampling') while bearing in mind not to 'linger' within one specific group and ensuring an even spread over the categories of women that were chosen as the project's focus.

The research is based on anthropological, qualitative methods such as interviews and did not employ large-scale quantitative methods. The sample size is very small, particularly when broken down by profession, and does not allow me to responsibly draw meaningful conclusions based on that marker. Therefore, I have chosen a different approach, and the analysis in this article focuses on the linguistic means of referring to 'gender mixing' and 'gender segregation', as well as the arguments interlocutors use to position themselves towards those phenomena.

\section{The history of women-only public spaces and ikhtilät}

The development of women-only public spaces is connected to the Saudi state's enrichment after the discovery and exploitation of oil, and, as Le Renard has argued, 'governmental discourses, including laws, measures, and policies, have served to perpetuate and consolidate the principle of gender segregation' (Le Renard 2008: 611).

Important factors influencing the position of women and supporting stricter and new forms of public gender segregation were the discovery and exploitation of oil, the process of urbanisation, and the rise of the revivalist Islamic Awakening movement ${ }^{2}$ and its discourse on segregation. These developments will be examined in the sections below, taking the proclamation of the (third) Saudi state in 1932, when the kingdoms of the Najd and the Hejaz were unified into the Kingdom of Saudi Arabia, as a starting point. Not long after unification, in 1938, oil was discovered.

\section{Oil and urbanisation}

The discovery of oil in 1938 and its subsequent exploitation led to the gradual development of wealth in Saudi Arabia in the 1940s. Early in the 1940s, the first oil wealth enabled, more than before, some elite families from Jeddah to spend time in i.e. Egypt. The experience abroad changed amongst others elitist people's views on girls'

\footnotetext{
2 The Islamic Awakening movement (sahwa islamiyya or șahwa) in Saudi Arabia first emerged in the 1960s and gripped Saudi universities in the 1970s and 1980s, while it rose to prominence in the 1980s. Saudis who were part of the Islamic Awakening movement combined their traditional Salafi theology with the ideas of the Muslim Brotherhood about political matters. These ideas had taken hold in the Islamic Awakening movement through members of the Muslim Brotherhood who had sought refuge in Saudi Arabia due to persecution by their Ba'thist and Nasserist governments. See also ICG, 2004. Other (regional) developments such as the Soviet invasion of Afghanistan and the Islamic revolution in Iran also influenced the politicisation of Saudi Islam.
} 
education. Al-Torki describes how upon return to Saudi Arabia in the mid-1940s some elite families would enrol their daughters in informal schools, where they would learn needlework and basic arithmetic, and would memorise passages from the Qur'an (Al-Torki 1986: 19).

The Ministry of Education was founded in 1953 with public schools for boys (not girls) opening for the first time in that year (Al-Munajjed 1997: 60). During the 1950s an increase in popular demand for formal girls' education started to emerge. Some young Saudi men who had been educated abroad expressed their need for 'educationally compatible wives' (Al-Munajjed 1997: 61). In 1955, the Dar al-Hanan school in Jeddah was the first private school for girls to open in Saudi Arabia.

Some religious scholars ('ulama') however, opposed girls' education, claiming that education would corrupt girls' morals and destroy the foundations of the Saudi Muslim family. Nevertheless, backed by the increasing income from oil, king Faisal (r. 196475) 'made the education of girls a priority' (Al-Rasheed 2010: 117). He insisted 'that all Saudis should be provided with educational opportunities within an Islamic framework' (Al-Munajjed 1997: 61-2), quoting the Qur'an and sayings (hadith) of the Prophet Muhammad to convince conservative elements that Islam does not oppose women's education. King Faisal persuaded the opposing religious scholars that education would also contribute to girls' Islamic education, making them better Muslim mothers (Al-Munajjed 1997: 63). ${ }^{3}$ Simultaneously, reports are known of several writers, journalists, and poets who had also been calling for educating girls (Al-Rasheed 2013: 78). It was however not until the religious scholars confirmed that girls' education was in accordance with Islam that conservative families started sending their daughters to school (Al-Munajjed 1997: 64), albeit separate from boys. Education for women, thus, is the first field in which the concept and practice of gender segregation in the public domain was introduced.

The developing oil industry led to an increased demand for labour in the cities in both the industrial and governmental sectors, which in turn led to a substantial number of people moving into cities. Whereas in the rural areas both men and women worked and contributed to the family income, urbanisation resulted in a significant increase in men's salaries (Le Renard 2008: 613). Female salaries were no longer needed to sustain the family and women not working became a symbol of wealth and moral distinction (Le Renard 2008: 613).

\section{The rise of the Islamic awakening movement}

Saudi Arabia's economic and material development as well as the population's wealth reached unprecedented heights in the 1970s. Especially the rising oil prices as a result of the 1973 oil crisis led to fast economic developments. It was also a period of quick social changes that impacted the social structure of the country. But in 1979, angry at the fast pace of development in the country, a group of rebels lead by Juhayman al-'Otaybi ${ }^{4}$ lay siege to the Grand Mosque of Mecca. They claimed that Saudi society

\footnotetext{
3 This debate also took place in Egypt, Iran and the Sudan in the first half of the 20th century. See also Abu-Lughod ed., 1998 and Ahmed,1992.

${ }^{4}$ A religious militant who believed that the Al-Sa'ud had lost their legitimacy because of corruption and imitation of the West.
} 
had become immoral due to western influences such as cinema, working women, and sports, and that king Khalid (r. 1975-82) had not countered these developments. The militants' aim was to usher in a new age of purism. Hundreds of pilgrims were taken hostage. The incident rocked the Saudi monarchy to its core, not in the least because Saudi soldiers had to be aided by French commandos in order to end the siege.

As a consequence of the 1979 siege, 'the Saudis tried to seal the connection between themselves as rulers and adherence to a 'one true Islam' (Doumato 2009: 24). The conservatism that flowed out of this often targeted women as culture bearers, as a consequence of which their access to public spaces was curtailed (DeLong-Bas 2009: 19). Women started to dress more conservatively, donning cloaks (abayas) and the face veil (niqab), and female presenters disappeared from Saudi TV screens (Doumato 2009: 23-4). More women-only spaces started to develop in the public domain, with the first women-only branch of the al-Rajhi bank opening in Alshmaisi in 1979.

Three years after the siege, king Khalid died (r. 1975-82) and king Fahd (r. 19822005) ascended to the throne. 'Separation of the sexes and control of women by their guardians ${ }^{5}$ blossomed over the next several years into tangible indicators of what it meant to be Muslim, and the Saudi political leadership got behind the task of enforcement' (Doumato 2009: 24). During the 1980s, a period of consolidation, the Islamic Awakening movement gained more and more ground, and more women-only public spaces appeared (such as the afore-mentioned women-only banks), financed with oil revenues, strengthening and diversifying the field of women-only public spaces.

\section{The 1990-1991 gulf war, 9/11, and the national dialogue}

In the run-up to the Gulf War, American troops arrived in Saudi Arabia, and American female soldiers drove cars and army trucks. The presence of US troops on Saudi soil during the Gulf War triggered strong opposition from prominent shaykhs such as Salman al-'Awda and Safar al-Hawali (ICG 2004: 5). At the same time, it partially inspired forty-seven women to take the wheel in November 1990, protesting for their right to drive. The religious police ${ }^{6}$ demanded punishment and the government took the drivers' passports and fired those who were teachers.

Although the Gulf War led to some political reforms such as the Basic Law of $1992^{7}$ and the installation of the (appointed) consultative council (majlis al-shūrā) (Yamani 1996: 267), it also led to a heightened turn to conservatism, a trend that gained further momentum later in the 1990s. In this playing field and in order to sustain itself at the centre of contemporary politics in the kingdom, the Saudi monarchy had a continuing need to reaffirm its legitimacy as an Islamic government. In this struggle, women's issues were pushed to centre stage:

\footnotetext{
${ }^{5}$ In Saudi Arabia, every woman has a guardian (mahram). A guardian is a male family member (father, brother, husband, son, or paternal uncle) whose permission a woman needs to, for example, work, travel, and study.

${ }^{6}$ The religious police is the Committee for the Promotion of Virtue and the Prevention of Vice, colloquially known as the mutawa' $a$ or the hay'a. They have, amongst others, the power to enforce 'proper Islamic dress', to arrest unrelated males and females caught socializing, and to enforce store closure during prayer time.

${ }^{7}$ The Basic Law lays down the basic system of governance of the Kingdom of Saudi Arabia (Saudi Arabia Basic Law of Governance 1992). It does not override shari'a, and article 1 of the Basic Law states that the country's constitution is the Qur'an and the sunna (traditions) of the Prophet Muhammad.
} 
One of the main characteristics of the contemporary political situation is that the issue of women's rights and behaviour has been placed at the centre of a potential power struggle between the 'ulama [religious scholars] and the state. The state uses the role of women within society to make symbolic gestures to confirm its commitment to Islam, for example by enforcing the wearing of the veil and the legal ban on women driving cars and by limiting the choice young women have in education and career choices, thus preserving the strict gender segregation in all public spaces (Yamani 2000: 95).

According to Dekmejian, after the 1990-91 Gulf war, 'Islam has become, once again, a two-edged political instrument - as the Kingdom's primary medium of selflegitimisation, and as the main venue of protest for opposition elements' (Dekmejian as quoted in Yamani 2000: 116). It is in the second half of the 2000s that we particularly see this playing out.

Within the context of those afore-mentioned demands for reform by various actors in the 1990s, the events of 9/11 and the domestic terrorist attacks on Riyadh compounds in 2003 and 2004 led to more pressure for reform - from outside as well as within the Kingdom. Then-crown prince 'Abdallah (r. 2005-2015) initiated the National Dialogues. ${ }^{8}$ The third National Dialogue (2004) focused on women, their duties and obligations, education, and participation in society and the labour market. Thirty-five men and thirty-five women participated in the dialogue. At the meeting, which was closed to the public, a clash seems to have taken place between those who oppose women's full participation in society and those who are 'with' women (Le Renard 2008: 619).

After the meetings, the participating women presented the same recommendations to 'Abdallah's wife, respecting and reinforcing the practice of gender segregation (Le Renard 2008: 618). After 'Abdallah's agreement, the recommendations were published. An interesting common feature of these recommendations is that 'they do not question gender segregation but rather reinforce it by suggesting the creation of more specific institutions for women' (Le Renard 2008: 619). The result of these recommendations was mainly to 'de-taboo' the women's issue and making the debate public with this 'state approval'.

\section{Gender segregation and public space in recent official Saudi Arabian discourses}

It is from the early 2000 s onwards that we see not only a further consolidation of women-only public spaces, but also a demand for the practice of ikhtilät. In order to placate both conservatives and more liberal-minded reformists in the Kingdom, both the developments of women-only public spaces and that of the practice of $i k h t i l a t$ in the public domain were supported by the government - although the latter less strongly.

In 2009, king 'Abdallah opened Saudi Arabia's first co-ed university where ikhtilāt would be practiced. The university, King 'Abdallah University for Science and Technology (KAUST) was built and financed by Saudi Aramco, the Saudi state oil

\footnotetext{
${ }^{8}$ The National Dialogues serve as a platform for dialogue in the Kingdom, based on two pillars: the Islamic shari'a and national integrity. Also refer to the King 'Abdulaziz Centre for National Dialogue (KACND) www. kacnd.org.
} 
company, and led to a strong debate about ikhtilat t amongst others among religious scholars. ${ }^{9}$ Six months after KAUST's opening, the director of the Mecca office of the religious police, Ahmad bin Qasim al-Ghamdi, gave an interview saying that 'there was nothing in Islam that prevents women and men from mixing in public places like offices and schools' (Gause 2010). Ahmad bin Baz, the son of former Grand Mufti ${ }^{10}$ shaykh 'Abd al-'Aziz b. Baz also publicly stated that there is a legitimate basis in Islamic law for a more lenient position on ikhtilāt (Gause 2010). ${ }^{11}$

Other, more conservative scholars such as Sa'd al-Shithri, a member of the Council of Senior 'Ulama', 12 are against a normalisation of ikhtilät because it can lead to 'a massive evil' such as 'corruption' (Meijer 2010: 14). Anything that can lead to that, i.e. mixed education, should therefore be forbidden.

In September 2011, king 'Abdallah announced the opening up of the consultative council (majlis al-shürā) to female members. He framed his decision as fitting with Islamic history, in which he said women played an important role. He also stressed that he had been advised on the matter by some of the country's religious scholars. The Grand Mufti, 'Abdel 'Aziz bin Shaykh, immediately publicly supported the king's decision. However, there was also opposition to the decision, and in January 2013, a few weeks before the king was to swear in the new consultative council including its female members, conservative scholars staged a protest outside the king's palace in Riyadh. While during the council's inauguration in February 2013 the female members sat in the same room as the male council members (though on a separate side), when in session the female council members enter the council by a women-only entrance and are seated in a room separate from their male counterparts.

Critics say that change is often more cosmetic and symbolic than substantive. King 'Abdallah walked a tightrope, using Islam to legitimise the House of Sa'ud's rule while at the same time it is one of the main avenues of opposition. 'Abdallah's strategy was one of political decompression: to make just enough concessions to appease Saudi Arabia's subordinate and disheartened peoples and relieve pressure for reform' (Yamani 2008: 144). It thus remains to be seen whether the (incremental) steps king 'Abdallah took on the path of reform will substantiate and gain momentum among the Saudi population under the new king Salman, or whether they will remain confined to small 'pockets' within Saudi society.

What this section has shown is that gender segregation into women-only public spaces has been implemented, institutionalised, and reinforced by processes of economic transition, education, urbanisation, and the influence of the Islamic Awakening movement, while especially since the second half of the 2000s a simultaneous development towards more ikhtilat t can be traced. On the one hand, the state uses the role of women within society to make gestures that confirm its commitment to Islam, supporting the development of women-only public spaces. On the other hand, it allows for the emergence of more ikhtilāt in the public domain.

\footnotetext{
${ }^{9}$ See also Meijer 2010.

${ }^{10}$ The Grand Mufti is the most influential religious authority in the Kingdom and is appointed by the king.

${ }^{11}$ From previous government stances it may be expected that 'any substantive change in Saudi policies on women's roles in society will be justified and explained by the government in terms of Islam' (Gause 2010). making al-Ghamdi and Bin Baz' statements all the more interesting.

12 The Council of Senior 'Ulama' (hay'at kibar al-'ulama') is Saudi Arabia's Council of Senior Scholars, and is the country's highest religious body. It is one of the bodies that advises the King.
} 
We saw how the Saudi government balances its position among the various contesting streams in society by initiating both projects that support women-only public spaces and projects that support ikhtilat. In doing so the state, with the power that it has, creates a field of legitimacy that interlocutors can engage with, position themselves towards, and relate to. Turning now to our interlocutors, we will see observe how both these trends and attitudes towards women-only public spaces and ikhtilat $t$ are reflected in their personal views.

\section{Interlocutors' views on public participation: from women-only public spaces to ikhtilät to khilwa}

In the previous section we saw that the issues of women-only public spaces and ikhtilat are core issues in the Saudi debate on the participation of women in the public domain in the Kingdom. In this section, then, I will explore my interlocutors' views on segregation, ikhtilatt, and khilwa. Firstly, I will discuss these concepts. Secondly, we will take a close look at the attitudes of my interlocutors towards segregation, ikhtilät, and khilwa. Thirdly, I will shed light on the strategies that my interlocutors employ in dealing therewith in their daily lives.

We will see reflected in the discourses of my interlocutors those of the Saudi state and religious actors. This illustrates the point that the Saudi state tries to balance the various streams in society and shows an interplay between all these actors, with the state through its inherent power determining the field of legitimacy in which those discourses can take place. This means interlocutors too relate themselves to the phenomena of women-only public spaces and ikhtilāt.

\section{Contested concepts: segregation, ikhtilāt and khilwa}

Gender segregation - and its opposite, ikhtilāt - are ambiguous and contested concepts and practices, while with khilwa this is not the case. My interlocutors had well-articulated yet divergent ideas about what the former two concepts actually mean.

From an outsider's perspective, one would consider the situation in Saudi Arabia regarding the relations between men and women in the public domain as gender segregation. However, as was discussed, in Saudi Arabia itself the public discussion focuses on the concept and practice of ikhtilāt: the mixing of the sexes. It is interesting to note here that unlike the word ikhtilat t for 'mixing', the spoken Arabic language does not have one word for segregation. When asked for a word in Arabic that denotes 'segregation', most interlocutors had to think for a while, to then come up with words such as infișāl, fașl, iqsām, häjiz, and hijāb, all denoting variations of the English word 'separation', while immediately adding 'but we do not really use this word', indicating that these are artificial descriptions:

Euhm... euhm.... No I don't know. I'm not sure. The opposite of mixing [ikhtilät] ... it's separation [al-faṣl]... but it's not a term we really use. Faṣl... 
you have to add words, like separation between men and women [fașl bayn arrijāl wa-l-nis $\left.\bar{a}^{\prime}\right]^{13}$

The fact that gender segregation is 'the norm' or 'default' in Saudi society and ikhtilät the issue of public debate is thus reflected in the spoken Saudi Arabic: no word exists that is actually used for 'gender segregation'. It is interesting to note here that in the English language, no word exists in the spoken language that is actually used for 'mixing'. Rather, we speak of 'segregation', denoting the separation between the sexes.

Also conceptually, 'segregation' is not necessarily a clear notion when referring to a practice. For example, for some interlocutors a screen between men and women in a conference room amounts to segregation, because the screen divides the room into a male and a female section, each with their own entrance but with a shared view of the stage. For other interlocutors, however, this qualifies as ikhtilatt, as the men and women are present in the same room and might mingle during breaks.

Ikhtilāt also is not a straightforward notion. Ibtisām, a female activist from Jeddah who has worked on women's issues all her life recounted her experience at the Fifth Jeddah Economic Forum of 2005, where she proposed that with all the talk and debate about ikhtilät there should be an official definition of what ikhtilät is and is not, so that everyone knows what is being talked about when the word ikhtilat t is mentioned. She made the same proposal during the 2007 Economic Forum. ${ }^{14}$ As a result of these proposals, she said, the issue of ikhtilat twas taken up in the seventh National Dialogue, on work and employment, which took place in 2008. Nevertheless, Ibtisām said, the term still has not been officially defined.

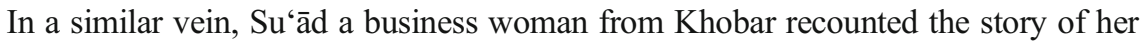
husband having to visit the office of the religious police, as their business was accused of employing 'a female waiter' and allowing 'a lot of mixing'. She said her husband entered the office, found five men of the religious police sitting at a round table, and asked:

What would you like us to do so you don't shut our store down? They [the five men of the religious police] had no answer. Everybody had a different opinion [on what ikhtilatt is], and that is the major problem when it comes to ikhtilät in a public place. It's subjective because there's no consensus and there's nothing written, and they won't write it down for you [what ikhtilät is/is not]. They will not put it in writing because each and every one has a different opinion. ${ }^{15}$

Both examples illustrate that the use and meaning of the term ikhtilät in the public debate and conversations is ambiguous. At the same time, many interlocutors said that in the Arabic language there is an understanding of the word ikhtilat as literally meaning 'mixing'. For example, mixing several ingredients to bake a cake. Khadija, a young female Islamic teacher from Jeddah explained it as follows:

\footnotetext{
${ }^{13}$ Interview with Mai, business woman, Jeddah, 21 September 2011.

${ }^{14}$ Interview with Ibtisām, activist, Jeddah, 21 September 2011.

${ }^{15}$ Interview with Su'ād, business woman, Dammam, 24 September 2011.
} 
In the language, it is you and me right now. I can sit with you, laugh with you, eat with you. That is ikhtilat in the language. It doesn't have anything to do with Islam. Any ikhtilāt. Also between women. Even with - excuse me - animals. I mix with them. I am in one place, and a cat sits next to me. That's ikhtilatt. ${ }^{16}$

Most interlocutors indicated that the basic definition of $i k h t i l a t$ is the mixing of more than one man and one woman in a public place such as a mall, the street, or in a hospital. It is this definition of ikhtilāt that this article employs.

A much less contested phenomenon than ikhtilat is khilwa. The basic definition of khilwa is a woman and a non-mahram man being together in a closed space (a mahram is a woman's male guardian who is either a direct blood relation or her husband). Some interlocutors added to that 'where no one sees you', so that a glass window separating the man and woman from a larger group of people would not amount to khilwa. Some interlocutors said that being in the car with the driver amounts to khilwa, because the car is a closed space and they are alone with him, while others say it is not a situation of khilwa because the car has windows (although often tinted) and moves around in a public space.

While disagreement exists among women whether ikhtilat t is or is not allowed, and should or should not be a larger part of public life in Saudi Arabia, consensus exists on the rejection of khilwa. The measurement seems to be whether or not contact between the man and the woman can - through the situation of khilwa - lead to relations ('alaqāt) or adultery (zina) that are both regarded as illicit. It is these relations, adultery, and societal chaos (fitna) that need to be prevented. One of Wahhabism's judicial pillars is 'the blocking of the means' (sadd al-dhara'i), meaning that actions that could lead to committing sins such as extra-marital relations and adultery must not be permitted. Interlocutor's ideas as to how to 'block the means' range from allowing women's participation in the public domain only through women-only spaces, to believing that $i k h t i l a \bar{t}$ is legitimate, to expressing the desire to prevent khilwa. This clearly indicates a lack of interest in illicit relations on the part of interlocutors and rather shows that the debate is about what constitutes legitimate access to public space for them.

Since the issue of khilwa is much less ambiguous among interlocutors than segregation and ikhtilät, the following section will not deal with khilwa. Similarly, the debate in Saudi Arabia itself centres around ikhtilat t and not segregation. Therefore, in the following section I will discuss those differing attitudes towards ikhtilät.

\section{Interlocutors' attitudes towards ikhtilāṭ}

In this section I will explore the diversity of attitudes towards ikhtilāt that my interlocutors displayed, illustrating their views by the ways in which they look at its practice. Three main categories of attitudes towards 'mixing' can be discerned among interlocutors: a minority believes ikhtilāt is unacceptable, while the second (majority) group thinks ikhtilat tis acceptable but only under certain conditions and circumstances. A (small) third group accepts and seems to actively promote ikhtilāt.

The first group, consisting of a minority of interlocutors, most of whom were located in Riyadh, were of the opinion that ikhtilät is an unacceptable practice. Most

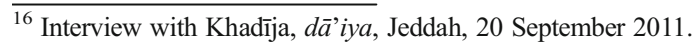


interlocutors indicated that Riyadh is generally more 'conservative' than Jeddah and that this can explain the attitude. Their main reasons for regarding ikhtilāt as an unacceptable practice are linked to ideas about the nature of men and women; customs and traditions ('adāt wa taqalīd); and Islamic history. As to the nature of men and women, there exists the idea that men may not be able to control themselves when working with women. As Najla', a young working woman from Jeddah stated: 'I would not want to work with men in the same room. [...] Men make stupid moves. ${ }^{17}$ Maysa, a da'iya from Riyadh, also does not want to work with men and made a conscious decision to work only with women, and uses a similar argument as Najla'. Maysa said:

For me it's a conscious choice to work in a non-mixed environment, only with other women. In my opinion it is much safer and much easier to work without men. Ikhtilāt would cause a lot of problems, such as rape. Countries where men and women work together there is a high percentage of rapes. ${ }^{18}$

So both Najla' and Maysa argue that working with men lead to problems such as (sexual) harassment of various degrees. To them, therefore ikhtilät is not an acceptable practice.

Regarding customs and traditions, interlocutors indicated that outside of Saudi Arabia, ikhtilāt would not be a problem for them, because people are used to it there - which is not the case in Saudi Arabia, where they say customs and traditions discourage ikhtilatt, and that should be respected. As such, ikhtilāt is not positioned as an acceptable practice in the Kingdom.

As to Islamic history, some interlocutors who are against ikhtilāt refer to Islamic history to support their standpoint, stating that mixing was not allowed at the time of the Prophet Muhammad. They say that for example in the Prophet's mosque prayer was separate, with the men praying in front and the women at the back. Interestingly, some of the interlocutors who are in favour of ikhtilät also refer to Islamic history to support their standpoint, stating that mixing was allowed at the time of the Prophet Muhammad. They too give the example of prayer in the Prophet's mosque, saying that the men would pray in front and women at the back, but that as they were praying in the same space this was not segregation but ikhtilāt.

The second group, composed of the majority of interlocutors, and especially in Jeddah, was of the opinion that ikhtilat t is acceptable under certain conditions and/or circumstances. Due to its character as a port and a hub for the pilgrimage receiving Muslims from all over the world, Jeddah is more open and, many interlocutors say, more open-minded and 'progressive'. The conditions and circumstances under which ikhtilāt should be allowed have a dimension of necessity; and a dimension of 'the Islamic regulations' (dawābit al-shar'iyya), expressed in ideas about behaviour; and of dress.

The first dimension is that of necessity (darūra). The state of darūra is. 'used to denote what may be called the technical state of necessity, and a wider sense (...)

\footnotetext{
${ }^{17}$ Interview with Najla', young working woman, Jeddah, 26 June 2010.

${ }^{18}$ Interview with Maysa, da'iya, Riyadh, 27 January 2011.
} 
to describe the necessities or demands of social and economic life' (Encyclopaedia of Islam).

The state of darüra is a state of necessity that allows someone to omit something that is required, or commit something that is not allowed in Islam. This means that if the necessities of the social or economic life demand it, someone may do something that under other circumstances they would not (be allowed to) do. 'Omnia, a thirty-four year old working woman who holds a university lectureship, teaching only women, said she was against ikhtilat in general but that when it came to necessities such as medical treatment in hospitals she did not have a problem with it: "if there is no choice, then a male doctor is fine in Islam because it is something necessary.' 19 'Omnia invokes necessity to legitimise the practice of $i k h t i l a t t$, which she is however principally against.

With respect to the second dimension of the rules and moral checks of the shari'a (dawābit al-shar'iyya), most interlocutors who agree with ikhtilāt within certain limits indicate that they are fine with the practice as long as the woman guards her behaviour and dress. Islamic Studies teacher Khadija for example refers to this as dawäbit alshar'iyya:

It [ikhtilāt] is not bad when I adhere to the rules and moral checks of the shari'a [dawäbit al-shar'iyya] that God has sent to us. I have rules and laws. And I have to walk with those so that I don't end up in forbidden ikhtilät [ikhtilāt muharram]. Because there is also permitted ikhtilāt [ikhtilāt masmūh $].{ }^{20}$

Here, permitted ikhtilāt is ikhtilāt within the dawäbit al-shar'iyya. For Khadīja, these regulations are proper dress - wearing the cloak (abaya) and the face veil (niqab) when going outside the house - and displaying proper behaviour: no laughing and joking but only a formal way of dealing with men. In that way, when holding on to these limits, the potential for illicit relations to occur is eliminated. Khadija explains that forbidden ikhtilāt is the type of ikhtilat that does not meet those regulations. It is a way of mixing with men that can lead to improper behaviour and relations.

The last category of those interlocutors who support actively promoting ikhtilat quite rare. Only very few interlocutors mention that they have stimulated ikhtilatt, and then in an indirect way. Hayat, a woman in her early thirties who used to teach business studies at King 'Abdulaziz University in Jeddah said she encouraged ikhtilāt through her teaching. She said she used to discuss ikhtilat $t$ in her lectures at university, saying that it is natural and no problem for a woman to be in ikhtilät. She said she thought that she influenced her students with her attitude and examples. ${ }^{21}$ Jihan, a middle-aged business woman from Jeddah who employs both men and women, also seems to stimulate ikhtilāt in an indirect way:

In my business we are mixed in my office. The women are in a separate room. Because this is what they want, the government, and if they come and check in

\footnotetext{
${ }^{19}$ Interview with 'Omnia, young working woman, Riyadh, 15 June 2010.

${ }^{20}$ Interview with Khadīja, dā' iya, Jeddah, 20 September 2011.

${ }^{21}$ Interview with Hayat, young working woman, Jeddah, 10 June 2010
} 
the office I am in the legal area, not doing anything wrong. But the meetings are mixed, and the girls sit with the men finishing their reports. They sit together at the computers finishing their accounting. This is how it should be. ${ }^{22}$

This practice should be specified in the business license: only women-only businesses can be run directly by women themselves and without a male director, and men are not allowed to enter the business. However, this business woman runs her business herself yet allows ikhtilat. By dodging the regulations, ${ }^{23}$ thereby risking to be shut down, this woman indirectly promotes ikhtilat t by allowing it on her work floor without having the necessary documents and status to back up the practice.

So the attitudes of my interlocutors towards to the actual use of mixed as well as women-only public spaces varied. Again, the small sample size does not allow me to draw meaningful conclusions based on interlocutors' different backgrounds. What we did see however is that interlocutors who are based in Jeddah are more likely to believe that ikhtilat $t$ is acceptable and permissible under certain circumstances than interlocutors who are located in Riyadh, who are more likely to be against ikhtilät. ${ }^{24}$ This can be explained by the fact that generally Jeddah is more 'open' than Riyadh and that therefore it is understandable that Jeddah-based interlocutors are more inclined towards a more lenient stance vis-à-vis ikhtilät.

The common denominator though is participation in the public domain, and whether this should take place in a mixed (mukhtalat) manner or through public spaces that are only-for-women. In the following section I will show that strategies as to how to achieve this participation vary.

\section{Interlocutors' strategies regarding their participation in the public domain}

The strategies that interlocutors put forward to achieve participation in the public domain vary. These strategies are not only related to ikhtilat as a way to participate in the public domain but mainly to the use of women-only public spaces. While most of the debate in Saudi Arabia is about the phenomenon of ikhtilat it is, after all, women-only public spaces that are the dominant mode of women's participation in the public domain.

Here, I will discern four types of strategies to negotiate women-only public spaces. A first, majority, group of interlocutors prefers to keep the status quo vis-à-vis womenonly public spaces. A second, small group, wishes to increase the presence of womenonly public spaces in and of itself. A third, minority group of interlocutors wants to increase the number of women-only public spaces as an intermediary phase towards more ikhtilāt. And finally a fourth, small group of interlocutors seems to undermine the presence of women-only public spaces.

Firstly, most interlocutors believe that the status quo is desirable, and that they have neither a desire for more ikhtilät nor a desire for more women-only public spaces. When asked whether she would like to see more or less women-only public spaces in

\footnotetext{
${ }^{22}$ Interview with Jihan, business woman, Jeddah, 21 September 2011.

${ }^{23}$ The Labour Law of 1969 forbade ikhtilat in places of work while at the same time it regulated and legitimised the presence of women in the public sphere into women-only offices where men were not allowed to enter. The Labor Law was amended in 2005 through Royal Decree No. M/51 and no longer mentions forbiddance of $i k h t i l a t$. Nevertheless, in practice the situation is not always clear. See also Le Renard $2014,46$.

${ }^{24}$ For the Eastern Province, the sample was too small to be able to comment.
} 
society, Muna ${ }^{25}$ answered no. She indicated that she wants to work in a women-only environment and that she made a conscious choice for such an organisation, but added that if it is a good position, she would work with men, because to her working is about achieving her dreams. At the same time, Muna does not see a need for an expansion of women-only workplaces. Her attitude is a pragmatic one: while her choice for working in a women-only office was conscious, her central argument is not a desire not to work with men but a desire to develop her potential.

Secondly, some interlocutors put forward that women-only spaces are their preferred way of interaction, and that they would like to see more of those spaces. For example, they would like to have more women-only malls, arguing that it would make them feel more relaxed and at ease being able to shop and work without wearing their abayas.

Not only women call for more women-only public spaces. In January 2011, a group of Saudi shaykhs and doctors launched a petition calling for the building of womenonly hospitals, so that women would have the opportunity of avoiding men when needing medical attention, and so that female doctors would be prevented from mixing with men. Female doctors also signed the petition that was submitted to the Ministry of Health and the consultative council (majlis al-shürā) (Sa'ud Sa'ud 2011). Most interlocutors however rejected the idea of women-only hospitals, stating that mixing in hospitals is something natural. Others argued that mixing in hospitals is necessary, because there are not enough specialised female doctors to avoid mixing. If there is no choice, receiving treatment from a male doctor is fine because the treatment is necessary. Most of the interlocutors who were in favour of this idea of women-only hospitals added that the project would anyway be unfeasible due to a lack of enough qualified specialised female doctors. ${ }^{26}$

Thirdly, a minority of interlocutors believe there should be an increase in womenonly public spaces as an intermediary phase towards more ikhtilāt. From this point of view, more women-only spaces will make society used to women's presence in areas where currently women are not active. Najla', a young working woman from Jeddah, illustrated this standpoint as follows:

A separate transportation system has to be made, like separate roads for men and women. Or the roads should be made available to men and women at separate hours. Until people get used to it, then they can make roads or hours together. ${ }^{27}$

Najla' reasons that the increased presence of women in the public domain - albeit separate from men - would increase society's comfort with women's presence in those areas, at which point society can and should move towards ikhtilät rather than segregation of women into women-only public spaces. In the case of separate roads for men and women, society would know of and see in the public domain these separate roads, allowing people to get used to women driving. Once society is indeed used to it, men and women should be able to drive on the same road or at the same time. From this point of view, women-only public spaces are seen as instrumental and as a phenomenon that will eventually be dismantled.

\footnotetext{
${ }^{25}$ Interview with Muna, young working woman, Jeddah, 19 June 2011.

${ }^{26}$ Such as for example Ahlam, dā'iya (and medical doctor), Riyadh, 25 January 2011.

${ }^{27}$ Interview with Najla', young working woman, Jeddah, 26 June 2011.
} 
Finally, a small number of interlocutors believe that the presence of women-only public spaces should be undermined immediately without any other phases, and put this attitude into practice by their behaviour. Daliya, a young business woman from Jeddah said about going to the Chamber of Commerce to arrange formalities for her business:

I don't like to go to the women's section. So I go to the men's section and they let me in. ${ }^{28}$

By displaying this type of behaviour, and by getting away with it in this environment, Daliya not only makes a clear statement with regards to her own opinion on ikhtilat t and women-only public spaces, but also tries to re-shape the boundaries of the permissible and acceptable.

\section{Liberation, empowerment, and the rise of women}

Conversations about women's public participation led me to ask questions such as how interlocutors relate to concepts of 'empowerment', 'women's liberation', and 'the rise of women'. The concepts of 'women in development' (Würth 2003). 'autonomy' and also 'empowerment' have been debated for their (un)suitability for Arab women. Whereas the first Arab Human Development Report (2002) by the United Nations Development Agency (UNDP) used the terminology 'women's empowerment,' (UNDP, 2002) in the 2005 Report - written by Arab scholars, policy makers, and practitioners and entirely devoted to the position of women in the Arab World - the descriptive term 'the rise of women' is preferred (UNDP, 2005). Here, we must acknowledge the discursive power of these concepts, that are often used in an international context while foregoing consideration of whether or not they find fertile ground outside a western framework. Thus, in interviews, I presented my interlocutors with the terms 'liberation of women'(tahrīr almar'a), 'empowerment' (tamkin al-mar'a), and 'the rise of women' (nuhud al-mar'a) in order to find out whether and if so to what extent these terms resonate with them. Do these terms have meaning to them, and if so how do they use them in the Saudi context, or do interlocutors have another way of approaching these issues?

\section{The concepts of 'liberation of women', 'empowerment', and the 'rise of women'}

The 'liberation of women' (tahrīr al-mar'a) has, for most interlocutors, a negative connotation. The term seems to denote the moral decline of the woman as a person (by for example, 'free relations' with men) and of society as a whole (by for example, the breakdown of the family). Only one interlocutor, an activist, said she found the ideas that she read in Qasim Amin's 1899 book 'The Liberation of Women' (Tahrīr almar'a) useful in order to reclaim Islamic history and the role of women therein. ${ }^{29}$ She related the story of how she had brought the book into Saudi Arabia from Egypt, as the

\footnotetext{
${ }^{28}$ Interview with Daliya, business woman, Jeddah, 17 June 2010.

${ }^{29}$ In his 1899 book 'The Liberation of Women' (Tahrīr al-mar'a), Qasim Amin advocated the modification of Egyptian laws on, amongst others, divorce and polygamy, supporting his arguments by using verses from the Qur'an.
} 
book is not allowed to be sold in the Kingdom (and thus does not have a wide readership).

The concept of 'empowerment' has been literally translated into Arabic as tamkin almar' $a$ and is a term that several interlocutors say comes from the United Nations. Almost all activists, as well as most business women, immediately recognised the term and were able to articulate what it means to them without further prompting. The term did not resonate immediately with all Islamic preachers and teachers, but after a little prompting they too were able to describe what they understand empowerment to be. To my interlocutors, empowerment consists of participation in public life, education, and economic empowerment.

According to my interlocutors, a central feature of empowerment is participation in public life: for example that a woman can become a Minister, a doctor, or a judge. ${ }^{30}$ Working, and for some holding public office is a sign of empowerment - not only of women themselves but also of society as a whole: some interlocutors frame empowerment not only as beneficial for herself or other women, but also to the rest of society.

Many of my interlocutors define access to education to be part of empowerment or even as its basis. The argument is that it is only with education that women can ascend on the ladder of public life and public office, and only through education that they can become decision-makers.

One activist said that she had made a conscious decision to focus on economic rather than social or political empowerment of women. She stated that she had chosen to focus on economic empowerment because tamkin al-mar' $a$ starts with financial awareness and ability. ${ }^{31}$

Finally, I discussed with my interlocutors the term 'the rise of women' (nuhud almar'a). This term was used in the 2005 Arab Human Development Report as a suggested alternative to the term 'empowerment'. The 'rise of women' was not a term that was immediately recognised and understood by most interlocutors. However, it was a term that resonated immediately with almost all of them. When presented with the term 'rise of women', some interlocutors reformulated it to 'the renaissance/rebirth of women' (nahdat al-mar'a) and immediately gave a definition of it. Awareness $\left(w \bar{a}^{6} i\right)$, and especially of awareness of the world around oneself and the awareness of rights, is an important component of 'the rise of women'.

Interlocutors also referred to the rise of women as 'the period in which we are now' and of the participation of women (mushtarakat al-mar'a), namely that women are increasingly participating in the public life. The September 2011 decision of king Abdallah to allow women to participate in the next round of the consultative council and the next municipal elections was often mentioned in this context.

In short, the term empowerment finds fertile ground mainly with the activists, and is defined mainly as participation in public life, education, and economic independence. Many of those activists are internationally connected and much aware of UN reports, and thus also of the terms that are used in those contests. The concept of the 'rise of women' is less known but resonates immediately with the majority of interlocutors, and is more broadly viewed as 'awareness of rights' and 'participation in society'. Importantly, central to both ideas is the participation of women (mushtarakat al-mar'a)

\footnotetext{
${ }^{30}$ While women can study Islamic law and practice as lawyers, they cannot become judges.

${ }^{31}$ Interview with Sana', activist, Jeddah, 19 September 2011.
} 
in society, in public space. Interlocutors express those ideas much more in relation to the concept of $i k h t i l a t$, as we saw, and women-only public spaces, as strategies for achieving women's public participation.

\section{Towards a 'modern Saudi woman'}

So far, it has become clear that both women-only public spaces and ikhtilät are central to ideas about women's participation in public spaces in Saudi Arabia. As Deeb (2006) puts forward, gender is a basic component of discourses about being modern, and it is 'one of the central modalities through which modernity is imagined and desired' (Rofel 1999: 20). Women have historically played an important role as national and as cultural symbols, and are during transitional periods in a country's development often either linked to modernity or to tradition (Moghadam 2003: 105). This especially touches upon the female body, which is often a central site of political difference and of resistance to and critique of forces of Western modernity (Göle 1996: 1). Gendered power has and can take on many different forms (Abu-Lughod 1998), and the body, ' (...) as Michel Foucault puts it, is the locus of all struggles of power, which works by the organization and division of space.' (Göle 1996: 9). Dividing space into mixed and only-for-women spaces, gender segregation can be seen as both a regulatory and as an 'emancipatory' process. Gender segregation can be regulatory in that it determines which spaces are and which are not accessible to women, determining in which spaces they can and cannot participate in public life and develop activities. At the same time, they can be 'emancipatory' in that women-only public spaces can open up spaces to women that otherwise would remain closed to them if these did not exist; for example, women-only workplaces that can serve as a mechanism of inclusion rather than exclusion, enabling women to work as they would not have wanted to or be allowed to had the workplace been mixed.

Gender segregation is often perceived to be a consequence of tradition and conservatism of society. Abu-Lughod (1998) and Le Renard (2008). though, argue that 'reference to the traditional does not help us to understand the persistence and consolidation of gender segregation' (Le Renard 2008: 610). The 'modernism-traditionalism dichotomy' relegates 'women's domesticity to the realm of conservatism and tradition and labels women's emergence into the public sphere, whether in politics, employment, or education, as radical and new' (Abu-Lughod 1998: vii).

Göle argues that there is a continuous back-and-forth between affirming authenticity and the globalisation of modernity (Göle 2000: 92). She argues that this authenticity is not formulated in a political, cultural, and social vacuum but rather is formulated in a joint attempt to redefine that authenticity in a way that 'is no longer apologetic before Western modernity' (Göle 2000: 96).

Nonetheless, the discursive power of the West and people's relationship thereto, should not be underestimated As Lara Deeb formulated it, ideas about what is and is not modern, as well as judgements about that spring from various kinds of media 'and are backed by political, economic, and military power (Deeb 2006: 25). Indeed, as Deeb argues, it is almost impossible not to see Europe as a point of reference, if only due to cultural permeation through technology, satellite, and internet. But while Europe may still be a point of reference - 'a person, community, place, or thing is always 
modern as compared to some other thing, an other that is defined in the comparison as not modern or less modern' (Deeb 2006: 17) - modernisation is no longer equalled to Westernisation but rather dissociated from it. At the same time, this modernity can capture its own-ness, in a mode that is regarded as 'authentic' by those who live and experience this modernity.

As became clear in the historical overview, some state actors describe 'progress' and 'modernity' in their own way, legitimising women-only public spaces with an Islamic discourse, but how do women themselves view this? Do they view women-only public spaces as 'modern', or is, in their perspective, ikhtilāt part of this modernity?

When asked whether Saudi Arabia is a modern country, and to define that modernity, almost all interlocutors put forward the same characteristics. While technological inventions such as internet, cars and airplanes, but also scientific progress and certain research methodologies were identified to be central to modernity, so was Islam. Hanān, an activist for example, said that 'the idea that religion would not be part of modernity is an ignorant idea. ${ }^{32}$ To almost all interlocutors, Islam sets the limits (hudīd) of modernity:

The internet, the Blackberry or the computer, they're not forbidden [harām] in the religion. You use them, but with limits $[b \bar{\imath} h u d \bar{u} d]$. For example, I use my mobile for relations with my family, with my children. But not for forbidden relations ['alaqāt muharrima], for the opposite of family relations. That is from the religion. ${ }^{33}$

Material progress, most women I spoke with argue, must take place within the limits and framework of Islam and its interpretations. As such, modernity has both a material and a religious dimension.

The majority of interlocutors make a distinction between modernisation and westernisation (taghrīb). Westernisation is most often defined as copy-pasting whatever comes from America or Europe: food, clothes, speech, and morals. Most women I spoke with reject the (perceived) secularity of the state and society, and only very few proposed a separation of religion and the state. 'Liberation of women', either mentioned literally or described as such, is associated with westernisation. Most interlocutors who include the women's issue in their description of westernisation reject the idea of women being able to have relations outside of the framework of marriage. Modernisation, on the other hand, is taking 'the positive, good things ${ }^{34}$ from them [the west] and leaving the bad things that the religion does not agree with. ${ }^{35}$ As such, the majority of women I spoke with indicate that they consider Saudi Arabia to be a modern Islamic country.

When asked whether ikhtilatt, or women-only public spaces, or both are part of that modernity, varying responses came. An activist, who works on women's issues for a charity, was adamant that 'segregation [fașl] is part of modernity [hadātha] and

\footnotetext{
32 Interview with Ḥan̄n, activist, Jeddah, 20 September 2011.

${ }^{33}$ Interview with Jamīla and Nūr, dā'iyāt, Jeddah, 19 September 2011. Quote: Nūr.

${ }^{34}$ Earlier on in the interview, Khadija had mentioned what those 'good things' are: 'Look, I can use a mobile phone. It is modern. Facebook, it is modern. Internet, cars, planes, cameras, air conditioning...So I can take things from modernity that go with the dawābit.'

${ }^{35}$ Interview with Khadīja, dä'iya, Jeddah, 20 September 2011.
} 
development [tatawwur]. For example, this meeting [a women-only meeting of the charity she volunteers for], is not that development? But if there were men here it would not be development [tatawwur] at all. ${ }^{36}$ Hanān here says that she believes that men and women would be preoccupied with each other rather than the content of the meeting. But another woman I interviewed, a $d \bar{a}^{6} i y a$, stated that not women-only public spaces but ikhtilāt is part of modernity - but only if the woman wears her headscarf (hijäb) and if both the man and the woman respect themselves and their limits. ${ }^{37}$

Interlocutors' notion of modernity thus does not consist only of material progress (education, infrastructure, gadgets) but also has a spiritual, religious dimension, leading us to Lara Deeb's 'enchanted modern' (Deeb 2006). It is the duality of material progress and religiosity that constitutes 'the Saudi modern' of which women's public participation, through ikhtilat as well as through women-only public spaces, is a component.

\section{Conclusion}

This article has, firstly, attempted to show how the developments of women-only public spaces and ikhtilät are tied to the historical development of Saudi Arabia. It was shown that especially since the second part of the 2000s, the state has also supported both developments in the public domain in an attempt to appease the various streams in society and as one way of consolidating its own position as the ruling family.

Interlocutors have adopted as well as challenged these developments. This article demonstrated that the concepts of segregation and ikhtilat $t$ are ambiguous and contested by various actors, including and importantly, interlocutors themselves. They negotiate their daily realities with regards to women-only public spaces and ikhtilät while (re)producing or contesting women-only public spaces. Their strategies when dealing with women-only public spaces and ikhtilāt vary from wanting to keep the status quo; wishing to strengthen women-only public spaces; strengthening them as an intermediary phase towards more ikhtilat, or attempting to undermine them.

I argued that women are often considered to be 'culture bearers,' and as such the women's issue is an area in which notions of progress and modernity are negotiated. Interlocutors actively engaged in giving meaning to modernity. Their perception of modernity does not consist only of material progress (e.g. internet, television, mobile phones, infrastructure) but also has a religious dimension grounded in Islam, leading to what Lara Deeb (2006) has called an 'enchanted modern'.

Open Access This article is distributed under the terms of the Creative Commons Attribution 4.0 International License (http://creativecommons.org/licenses/by/4.0/), which permits unrestricted use, distribution, and reproduction in any medium, provided you give appropriate credit to the original author(s) and the source, provide a link to the Creative Commons license, and indicate if changes were made.

\footnotetext{
${ }^{36}$ Interview with Hanān, activist, Jeddah, 20 September 2011.

${ }^{37}$ Interview with Fāṭima, dā'iya, Dammam, 24 September 2011.
} 


\section{References}

Aarts, P. R., \& Meijer, R. (Eds.) (2012). Saudi Arabia between conservatism, accommodation, and reform. The Hague: Clingendael Netherlands Institute of International Relations.

Abu-Lughod, L. (Ed.) (1998). Remaking women: feminism and modernity in the middle east. New Jersey: Princeton University Press.

Ahmed, L. (1992). Women and gender in Islam. New Haven: Yale University Press.

Al-Munajjed, M. (1997). Women in Saudi Arabia today. London: Macmillan.

Al-Rasheed, M. (2010). A history of Saudi Arabia. Cambridge: Cambridge University Press.

Al-Rasheed, M. (2013). A most masculine state: gender, politics, and religion in Saudi Arabia. Cambridge: Cambridge University Press.

Al-Torki, S. (1986). Women in Saudi Arabia. Columbia: Columbia University Press.

Amīn, Q. (1899). Tahrīr al-mar'a (the liberation of women). Cairo. Translated by: Peterson, S. (2000). The liberation of women \& the new woman. Cairo: American University in Cairo Press.

Deeb, L. (2006). An enchanted modern: gender and public Piety in Shi'i Lebanon. Princeton: Princeton University Press.

DeLong-Bas, N. (2009). The Freedoms Saudi Women Really Want. In: The Kingdom of Saudi Arabia, 19792009: Evolution of a Pivotal State. A Special Edition of Viewpoints. Washington, DC: The Middle East Institute.

Doumato, E. (2009). Obstacles to Equality for Saudi Women. In The Kingdom of Saudi Arabia, 1979-2009: Evolution of a Pivotal State. A Special Edition of Viewpoints. Washington, DC: The Middle East Institute.

Encyclopaedia of Islam (2nd edition). Darūra. Brill Online. http://referenceworks.brillonline.com/browse/ encyclopaedia-of-islam-2. Accessed 27 October 2014.

Foley, S. (2010). The Arab Gulf states, beyond Oil and Islam. Boulder and London: Lynne Rienner.

Gause, G. (2010). Saudi Arabia: The Second Sex and the Third Rail'. Foreign Policy. http://mideast. foreignpolicy.com/posts/2010/04/19/saudi_arabia_the_second_sex_and_the_third_rail. Accessed 13 June 2010.

Göle, N. (1996). The forbidden modern. Ann Arbor: University of Michigan Press.

Göle, N. (2000). Snapshots of Islamic Modernities. Daedalus, (129)1, 91-117.

Hamdan, A. (2005). Women and education in Saudi Arabia: challenges and achievements. International Education Journal, 6(1), 42-64.

International Crisis Group (ICG) (2004). Saudi Arabia backgrounder: who are the Islamists? ICG middle east report, (31). Amman, Riyadh, Brussels: International Crisis Group.

King 'Abdul Aziz Centre for National Dialogue. (KACND). (2008). National Dialogue on Work and Employment. Summary of Meeting Conclusions. Riyadh: King 'Abdulaziz Centre for National Dialogue. kacnd.org/eng/siventh_meeting_conclusion.asp. Accessed 13 November 2011.

King ‘Abdul Aziz Centre for National Dialogue. (KACND). (2008). National Dialogue on Women's Rights and Their Obligation to Society. Summary of Meeting Conclusions. Riyadh: King 'Abdulaziz Centre for National Dialogue. kacnd.org/eng/Third_meeting.asp. Accessed 13 November 2011.

Le Renard, A. (2008). "Only for women": women, the state, and reform in Saudi Arabia. Middle East Journal, 62(4), 610-629.

Le Renard, A. (2014). A society of young women: opportunities of place, power, and reform in Saudi Arabia. Stanford: Stanford University Press.

Meijer, R. (2010). The gender segregation (ikhtilāt) debate in Saudi Arabia: reform and the clash between 'ulamà' and liberals'. Journal of Islamic Studies, 30, 2-32.

Moghadam, V. (2003). Modernizing women: gender and social change in the middle east. London: Lynne Rienner Publishers.

Rofel, L. (1999). Other modernities: gendered yearnings in China after socialism. Berkeley: University of California Press.

Sa’ud, F. (2011). Shuyūkh wa-Atbā' sa'ūdīyūn yutālibūn bi Mustashfayāt Nisā’iyya yumna’u fỉhā al-Ikhtilāț bi-l-Rijāl' (Saudi shaykhs and doctors demand women-only hospitals in which mixing with men is forbidden), Al-'Arabiyya. http://www.alarabiya.net/articles/2011/01/17/133902.html. Accessed 18 January 2011.

Saudi Arabia Basic Law of Governance. (1992). Ministry of Higher Education www.mohe.gov.sa/en/ studyinside/aboutKSA/Pages/system-of-governance.aspx. Accessed 13 December 2010. 
United Nations Development Programme (UNDP). (2002). Arab human development report 2002: creating opportunities for future generations. United Nations Development Programme: United Nations Publications. New York.

United Nations Development Programme (UNDP). (2005). Arab human development report 2005: towards the rise of women in the Arab world. United Nations Development Programme: United Nations Publications. New York.

Würth, A. (2003). Stalled reform: family law in post-unification Yemen. Islamic Law and Society, 10(1), 1233.

Yamani, M. (1996). Feminism and Islam: legal and literary perspectives. New York: Ithaca Press.

Yamani, M. (2000). Changed identities: the challenge of the new generation in Saudi Arabia. London: Chatham House Royal Institute of International Affairs.

Yamani, M. (2008). The two faces of Saudi Arabia. Survival, 50(1), 143-156. 